\title{
The influence of carbon content in the mixture of substrates on methane production
}

\author{
Rafał Mulka $^{1} \cdot$ Wiesław Szulczewski ${ }^{1} \cdot$ Józef Szlachta $^{2} \cdot$ Hubert Prask $^{2}$
}

Received: 30 June 2015 / Accepted: 13 October 2015/Published online: 23 October 2015

(C) The Author(s) 2015. This article is published with open access at Springerlink.com

\begin{abstract}
A lot of different chemical reactions take place in the biochemical process of biogas formation but the most important of them include the reaction of bonding carbon dioxide with hydrogen and the decomposition of acetic acid. Other factors, such as temperature, $\mathrm{pH}$, etc., only limit the amount of methane or, in extreme cases, they even stop the process of methane formation. The paper presents an analysis of the influence of the amount of available carbon in the substrate and inoculum on biogas production, as well as of the validity of the relation between methane production and carbon/hydrogen ratio which is often mentioned in the literature. The analyses were made on the basis of the results of several dozen laboratory experiments on methane production for five groups of substrates: cultivated plants, animal faeces, plant waste, animal waste and municipal waste. This provided the basis for the formulation of the conclusion that there is no significant relation between the carbon/hydrogen ratio and methane production, and an alternative biogas calculator was suggested to estimate methane production with the known content of carbon in the substrate and inoculum. This calculator was also adapted to the conditions of agricultural biogas plants, and then it was tested in those conditions. It should also be mentioned that the innovative aspect of the study presented herein is the model developed
\end{abstract}

Rafał Mulka

rafalletto@yahoo.de

1 Department of Mathematics, The Faculty of Enviromental Engineering and Geodesy, University of Enviromental and Life Sciences, Wrocław, Poland

2 Institute of Agricultural Engineering, The Faculty of Life Sciences and Technology, University of Enviromental and Life Sciences, Wrocław, Poland for the estimation of methane production on the basis of carbon content only, providing estimates with a smaller error than in the case of the calculators!

Keywords Biogas $\cdot$ Methane $\cdot$ Coal $\cdot$ Mathematical model

\section{Introduction}

A lot of emphasis has been placed over the recent years in the European Union on the development of renewable sources of energy which can replace even large coalburning power plants (for example, Poland is committed to increase final gross energy consumption from renewable sources-by the year 2020 Igliński et al. 2015). One 2-MW biogas plant is not much compared to some coal-burning power plants power output of which can be $4 \mathrm{GW}$, but 1000 such agricultural biogas plants can provide not only a high economic profit but also utilise farm waste. What is very often an obstacle in such investments is the uncertainty of the energy gain from available substrates. In such a situation, a simple mathematical model, a biogas calculator or an artificial neural network model (Behera et al. 2015), could be very helpful in estimating methane production from a given mixture of substrates-with no big error. The biochemical process of biogas formation (biogas is composed mainly of methane and carbon dioxide Sattler 2011) involves a lot of different chemical reactions, the most important of which include the reaction of bonding carbon dioxide with hydrogen and the decomposition of acetic acid caused by the enzymes excreted by microorganisms participating in the process (Sattler 2011). As a result, the amount of available carbon in the substrate determines the maximum amount of methane and carbon dioxide which 
can be formed. The other factors, such as temperature or $\mathrm{pH}$, will only limit the amount of methane, or in the case when the conditions for the microorganisms living in the fermentor are inadequate, they will stop the process of methane formation. Furthermore, the use of an adequate inoculum during the production of methane in agricultural biogas plants has a significant influence, especially in the initial stages of biogas production (Pandey et al. 2011). A question arises then how much carbon there is in the substrate which can be used for methane production and whether it is possible to estimate the amount of biogas with acceptable accuracy. The first thing to consider when evaluating the usefulness of farm waste in biogas production is the content of dry matter and the total amount of organic matter (for example, for maize Rath et al. 2015). This is also how we know how much water and ash a given substrate has William (2000); however, it is unknown which part of dry organic mass in a given substrate is not decomposed in biogas production. One such substance which does not decompose is, for instance, lignin. Methane production is evidently lower in substrates with more lignin (Axaopoulos et al. 2001) Rafique. However, it is possible to prepare the substrate with the use of proper yeasts or enzymes in such a way that lignin can be decomposed during hydrolysis, and carbon compounds from lignin can be used to produce methane (Chandra et al. 2012). Currently, the most popular tool for the estimation of biogas production is a biogas calculator which estimates biogas production with the use of information about the content of dry matter, the content of ash (or the content of dry organic matter) and biogas production from a given substrate (the result is the product of those values) (Myczko et al. 2011). Unfortunately, the result is burdened with a large error. Biogas calculators hugely overestimate biogas production (they do not take into consideration, e.g. the substances which do not hydrolyse in biogas production) (Sławiński et al. 2012). Biogas calculators are based mainly on the product of dry matter, organic dry matter, biogas yield (determined in the laboratory) and methane content in biogas (also determined in the laboratory). In the first place, the error will result from the diversity of substrates. Biogas yield and methane content determined in the laboratory will differ considerably in relation to the region from which the plant material originates. Hence, the final results obtained during the testing of the calculator will be positive only where the substrates have been tested. Another reason for the overestimation of biogas (methane) production is leaving out from the analysis the content of non-degradable compounds included in the substrate, such as, e.g. lignin-hence, the estimated production is higher than the actual. Besides, biogas calculators do not take into account the fact that the content of carbon in the fermentor changes in time (in the case of continuous production), but calculate only the maximum production. However, in biogas plants of this type, the production curve is sinusoidal rather linear.

In relation to the above, the authors undertook to develop a simple mathematical model that will permit the estimation of biogas production for a broad spectrum of substrates of agricultural origin, not only those that were used during the testing of the model, but also substrates from other regions. Besides, the model is characterised by better accuracy compared to the biogas calculators, while retaining simplicity of approach to the problem. In this model, parameters, such as, temperature, $\mathrm{pH}$, and retention time, are not taken into consideration.

\section{Literature overview}

Benjamin Gompertz was the pioneer in modelling this type of processes. The model developed by him in 1825 was not developed to estimate biogas production but mainly to calculate the mortality of a population of living organisms. This was the basis for the development of the MakehamGompertz law which describes the dynamics of mortality of a population. That model, which was later further developed and modified, has been used to date in biology, medicine, e.g. to describe the growth of neoplastic cells or to estimate biogas or methane production (Ledakowicz et al. 2010). In 1962, Buswell and Mueller suggested the estimation of biogas production from substrate on the basis of its chemical composition. This method provided for a more precise evaluation of the substrate or cosubstrate in biogas production; however, it does not take into account the influence of other factors, such as temperature or $\mathrm{pH}$ (Gerber and Span 2008). In the literature, there exists also the equation which was created only by Buswell Hidalgo et al. (2014). A dozen or so years later, in 1976, Boyle used the model developed by Buswell and Mueller and suggested adding the content of nitrogen and sulphur to the equation. The calculation of the amount of ammonia and hydrogen sulphide became possible with that model. Unfortunately, also in this case, apart from the chemical composition, the model does not take into account other parameters of the process (Menardo et al. 2013). A totally different approach was applied in 1978 by Jewell who developed an empirical model to calculate biogas production on the basis of the functions of biomass degradation in continuous production (substrate is provided several times a day). That equation took into account the flow of biodegradable dry matter (i.e. without the participation of, e.g. lignin or other substances which are not degradable in biogas production), and it was the main basis for the calculations of daily biogas production (Minott 2002). When estimating methane production on the basis of more factors 
determining that process, Chen and Hashimoto took a more comprehensive approach. Hashimoto was the first to take into account, in 1978, the rate of growth of microorganisms which he related to the temperature of liquid manure in the digester and empirically established coefficients. This model is still used to study the influence of individual factors on the microorganisms living in agricultural biogas plants. This model was further improved over the next years, taking into account the rate of growth of bacteria and the input of organic dry matter (Axaopoulos et al. 2001). In 1994, Tabasaran proposed a model taking into account a greater number of factors. That model primarily took into account the influence of carbon content on biogas production (Wandrasz and Landrat 2002). In 1995, Toprak proposed an empirical model to estimate biogas production only on the basis of the ambient air temperature (Toprak 1995). A similar approach was presented in 1999 by Hobbs whose model directly estimates the emission of methane from pig manure in the function of time. The model was developed only for one substrate, and it does not take into account any other factors (Wu et al. 2006). In 1999, Andara and Esteban developed a two-step kinetic model to estimate methane production from pig manure. That model takes into account a great number of factors (reaction time, concentration of microorganisms, constant cellular performance) and that is why the equations describe the process of biogas formation much better. The conducted experiments demonstrated a good fit of the model; however, its basic disadvantage is that it has been tested only on one substrate, and consequently, it is highly probable that the efficiency of that model will be much lower for other substrates (Andara and Esteban 1999). At the same time, Masse and Droste proposed a model based on the analysis of digestion in anaerobic conditions, introducing the socalled biological activity (Masse and Droste 2000). In 2002, Scott and Mionott developed the most advanced model in respect of the factors which affect the evaluation of biogas production. Apart from estimating biogas production, that model is also used to calculate the total substrate degradation. To some extent, the above model is based on the model developed by Hashimoto because it can also be used to establish the rate of growth of microorganisms. It has already been rather well verified, and the results achieved provide good grounds to claim its good fit to the results achieved in experiments ( $\mathrm{Wu}$ et al. 2006). Another model published in 2006 is the model presented in Battone (2006). The author of the model estimates methane production on the basis of the loss of mass and the concentration of degradable components. In the case of the model published in El Monayeri et al. (2013), the amount of methane is estimated on the basis of the known chemical demand for oxygen, efficiency of methane and volatile suspended solids. The last of the mathematical models presented in this paper was developed on the basis of the model by Gompertz and adapted to estimate biogas production (Latinwo and Agarry 2015). Obviously, the review presented above does not comprehensively describe the models of biogas production, but it can be claimed that most of them require very detailed information about the process or are relatively imprecise. The authors do not know a model of methane production, which is actually based only on carbon content in the substrate and inoculum. Developing such a simple relation might dramatically simplify the estimation of biogas production and consequently become a real alternative to biogas calculators.

\section{Materials and methods}

The method of estimation of methane production presented in this paper was developed on the basis of laboratory tests conducted in the biogas laboratory at the Institute of Agricultural Engineering, the University of Environmental and Life Sciences in Wrocław, Poland. The methodology of studies of the fermentation process complied with DIN 38414-S8. The inoculum which was used in the analysis was the post-digestate formed on the basis of manure with dry matter content of $3.52 \%$ and carbon in dry matter at $42 \%$. The nitrogen content in dry matter was $1.2 \%$. The use of post-digestate as an inoculum and mixing it with the substrate guaranteed that the resulting mixture contained the appropriate species of microorganisms. The sum of the inoculum used and the input material was always 400 grams. The temperature for all samples was $38{ }^{\circ} \mathrm{C}$ and it was constant. Also in the case of the tank volume-for all samples, it was $1.1 \mathrm{dm}^{3}$ and it was constant Fugol (2013). pH was 7 and it was constant (although some differences were noted depending on substrate). Enzymatic additives by Baktoma, such as adenosine diphosphate (ADP) and lysosomal palmitoyl-protein thioesterase (PPT), were used for some substrates in which the production of both biogas and methane was the highest. The enzymes were added in doses of $30 \mathrm{~g}$, dissolved in distilled water, then applied in that form to the substrate under study. The ratio of the enzyme prepared in that manner was ca. 1:10 relative to the charge in the fermentor-10 millilitre of enzyme prepared (concentration: $0.03 \%$ ) was added to the fermenter which volume was 400 millilitre. In the case of biogas plants, information from six biogas plants was used for the tests. The data included primarily the average daily methane production during the process, daily dose of substrate and carbon content in the substrate, as well as the temperature of fermentation, $\mathrm{pH}$, HRT time, and tank size. 


\section{Substrates used in the analysis}

The following groups of substrates were used for the analysis conducted in the laboratory: cultivated plants (alfalfa, silage, spartina, phalaris, millet), animal faeces (liquid manure, manure, poultry droppings), plant waste (grape pulp, pulp and beet roots, molasses), animal waste (bull blood, content of stomachs and reticulorumens of calves and bulls), municipal waste (post-flotation waste). The following substrates were used for the analysis conducted in the agricultural biogas plants: pig manure, cattle manure, corn silage, grass silage, green mass, triticale, and beet pulp.

\section{Analysis}

With a lot of data from methane production in laboratory conditions, the first thing to verify was the influence of the carbon/nitrogen ratio on its production. The literature can provide the results of studies with conclusions about the optimal value of that ratio for maximum production (Kameswari et al. 2014). The analyses conducted demonstrate that there is no such significant relation (Fig. 1). The production was equally good for substrates where that ratio was close to 50 and for those where that ratio was about 18 .

As mentioned above, several chemical reactions take place in the biochemical process of biogas formation, but the most important of them include the reaction of carbon dioxide bonding with hydrogen and the decomposition of acetic acid caused by enzymes excreted by the microorganisms participating in the process. Carbon included in the mixture must be then the key component in this process. As it was necessary to compare various substrates with one another, all the results of methane production for laboratories were first converted to millilitre of methane production per 1 gram of the mixture. Carbon content in the mixture was established on the basis of the following simple equation:

$C=\frac{M \cdot T S_{p} \cdot C_{p}+M_{j} \cdot T S_{p j} \cdot C_{p j}}{M+M_{j}}$,

where $M$ is the mass of substrate $[g] ; M_{j}$ is the mass of inoculum $[g] ; T S_{p} \in[0,1]$ is the fraction of dry matter included in the substrate; $T S_{p j} \in[0,1]$ is the fraction of dry matter included in the inoculum; $C_{p} \in[0,1]$ is the fraction of carbon content in dry mass of substrate; $C_{p j} \in[0,1]$ fraction of carbon content in dry mass of inoculum; and $C$ is the total carbon content [-].

The relation between total methane production and carbon content in the mixture calculated on the basis of the Eq. 2, for a wide range of substrates, is evidently exponential (identical to the traditional growth of microorganisms for batch cultures (Schlegel 2003; Fig. 2).

$B=\mathrm{e}^{(45 C),}$

where $\mathrm{B}$ is the methane production $[\mathrm{ml} / \mathrm{g}]$.

The coefficient of determination for the presented calculator slightly exceeded 0.7 , which is why it can be claimed that there is a strong relation between biogas production and carbon content defined this way in that group of substrates. The result can be still improved, by
Fig. 1 Influence of the carbon/ nitrogen ratio in the mixture of substrates on methane production

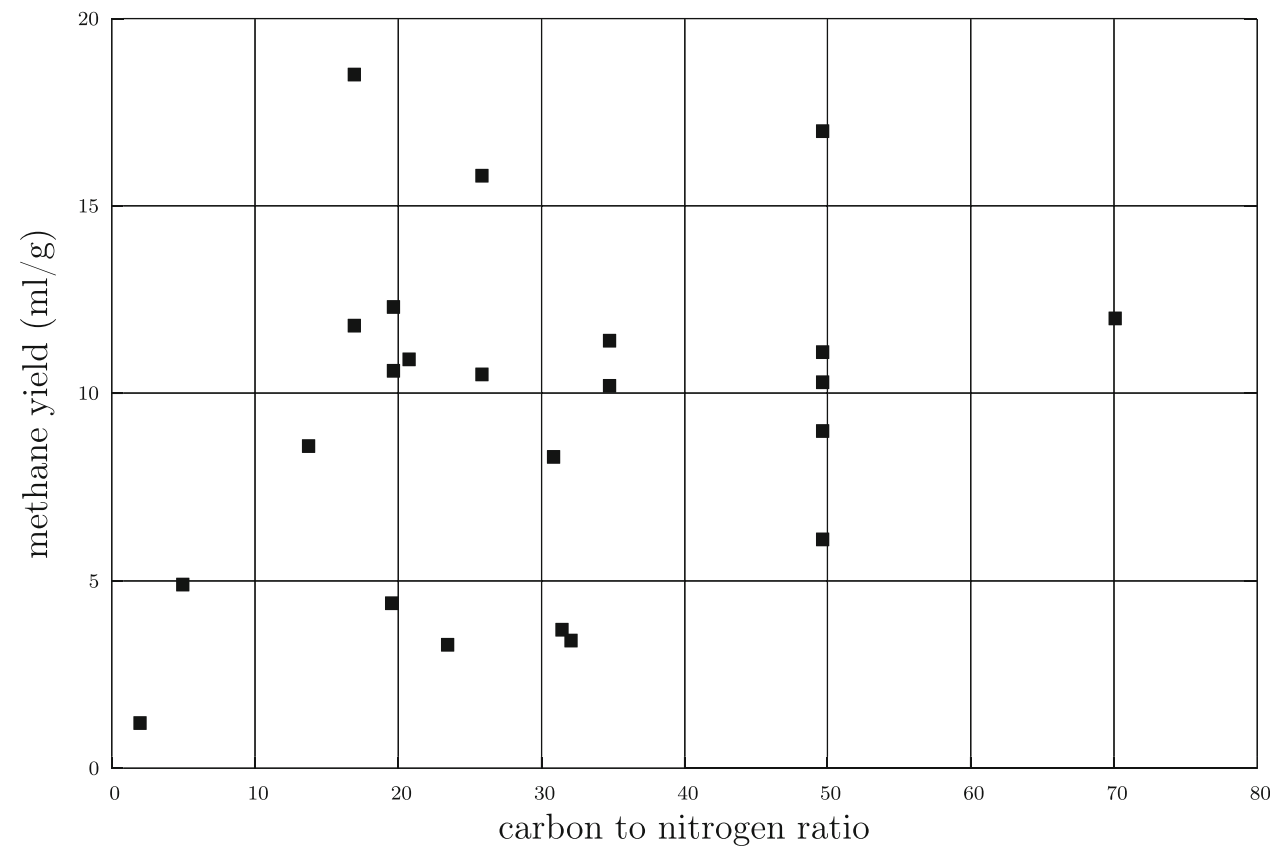


Fig. 2 Influence of carbon content in the mixture of substrates on methane production

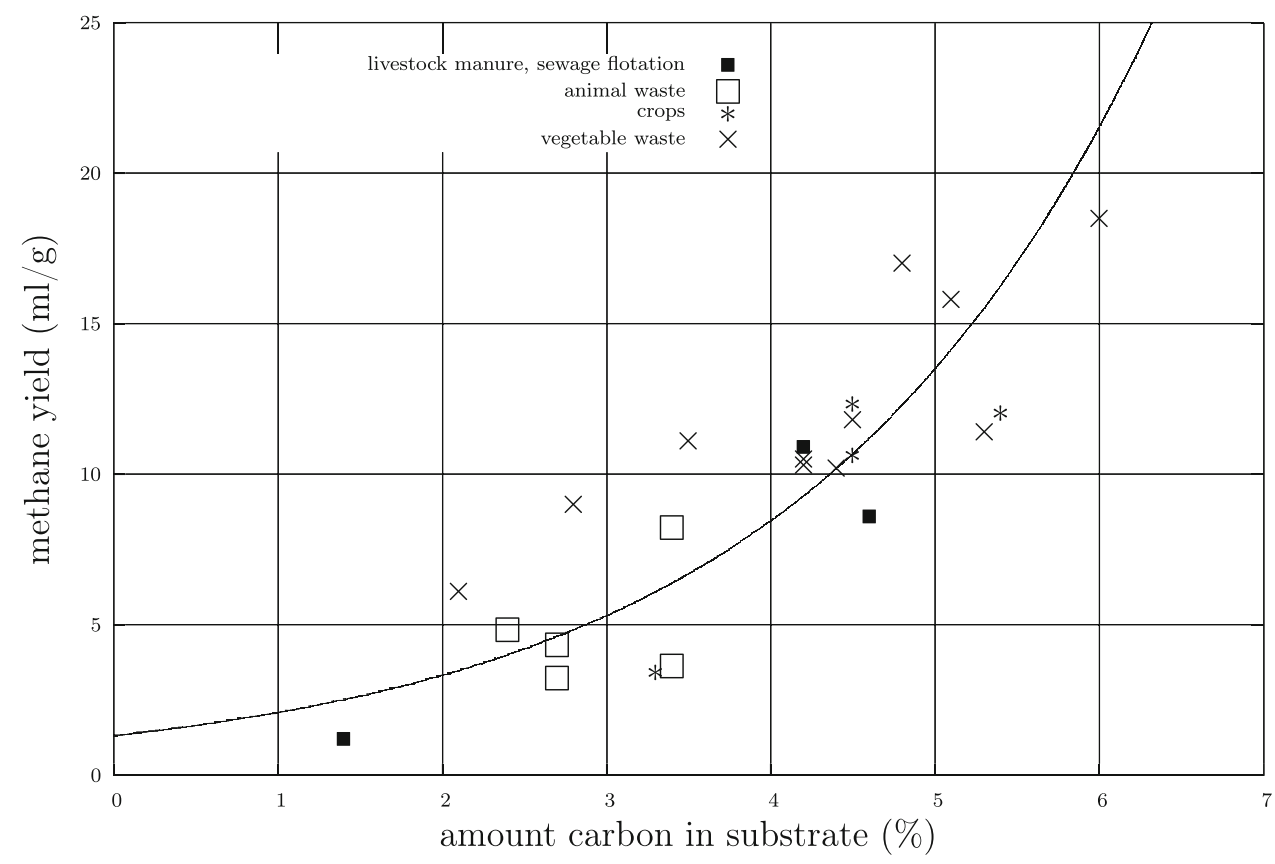

omitting beet pulp in the analysed group. The coefficient of determination grows then to 0.79 (Fig. 3).

In order to estimate methane production in agricultural biogas plants, a mathematical model was developed on the basis of the proposed relation between methane production and carbon content. First, the initial carbon content in the digester is calculated on the basis of known percentage of carbon content in the provided daily mixture of substrates and HRT time:
$C_{0}=H R T \cdot \sum_{k=1}^{n}\left(M_{k} \cdot T S_{p_{k}} \cdot C_{p_{k}}\right)[$ tony $]$,

where $M_{k}$ is the mass of k-th substrate [tona $] ; S_{p_{k}} \in[0,1]$ is the fraction of dry mass of k-th substrate; $C_{p_{k}} \in[0,1]$ is the carbon content in dry mass of k-th substrate; and $C_{0}$ is the total carbon content [-].

Over the subsequent days, the amount of available carbon in the digester was calculated in the following way:
Fig. 3 Influence of carbon content in the mixture of substrates on methane production without beet pulp and roots

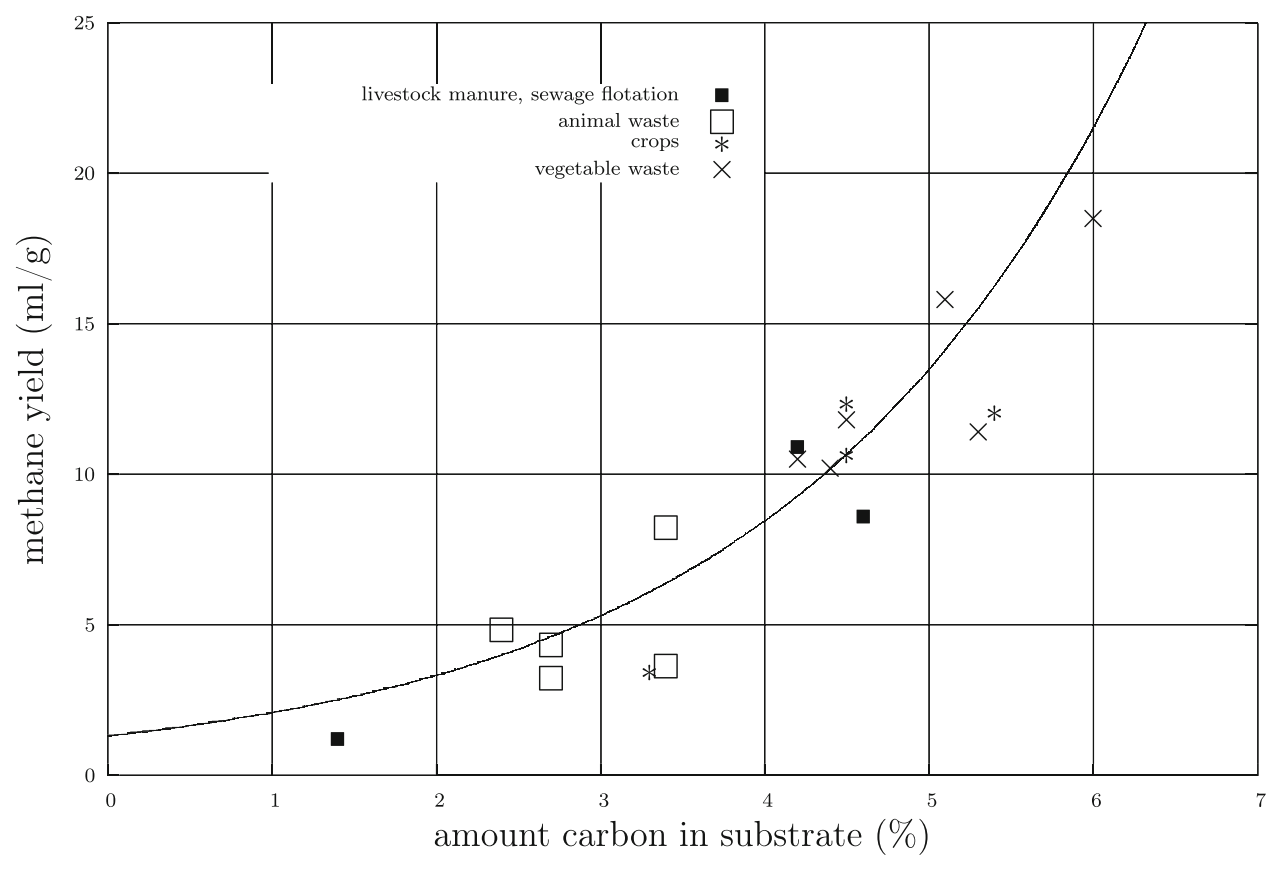




$$
\begin{gathered}
C_{i+1}=\left(C_{i}-\left(C c o_{i}+C c h_{i}\right)\right) \cdot\left(1-\frac{1}{H R T}\right) \\
+\sum_{k=1}^{n}\left(M_{k} \cdot T S_{p_{k}} \cdot C_{p_{k}}\right)[\text { tony }], \\
\left(i=0, \ldots, i_{\max }-1\right)
\end{gathered}
$$

With the amount of carbon in the digester, on the basis of Eq. 5, methane production in the successive days of production was estimated, additionally introducing a weight coefficient which takes into account the initial period of growth of microorganisms:

$B_{i}=W_{i} \cdot \mathrm{e}^{\left(45 C_{i}\right)}\left[m^{3} \cdot \operatorname{ton}^{-1}\right]\left(i=0, \ldots, i_{\max }-1\right)$

where

$W_{i}=\frac{Q_{i}}{\sum_{k=1}^{H R T} Q_{k}} ; Q_{i}=\mathrm{e}^{\left(-\mathrm{e}^{(\alpha(\beta-i)+1)}\right)}\left(i=0, \ldots, i_{\max }-1\right)$

It was assumed that $60 \%$ of carbon is used in the methane production during the process, whereas the remaining $40 \%$ is used in the carbon dioxide formation. With this assumption, it was possible to calculate the loss of carbon in the digester at each time stage, caused by methane production and formation of carbon dioxide.

In the experiments conducted at the laboratory of the UELS in Wrocław, those values varied within the range from about 40 to $70 \%$ in the case of methane, and from ca. 25 to $50 \%$ in the case of carbon dioxide.

\section{Results}

The model was evaluated on the laboratory scale (Eq. 2) on the basis of the relative root mean square error (RRMSE), model efficiency (EF) and the coefficient of residual mass (CRM). The best fit of the calculator is in the case when the value of RRMSE is close to 0 . The model efficiency (EF) is the measurement of the deviation of the values achieved with the model from the measured data in reference to the dispersion of the measured data. When its value is 1 , it indicates the ideal fit of the values achieved with the calculator to the values from direct measurements. When its value is 0 or negative, it indicates that the average value is a better predictor than the calculator. The coefficient of residual mass $(\mathrm{CRM})$ is the measurement of relations between the forecast and the measured values. When the value of CRM is 0 , it indicates the ideal fit, its positive or negative values indicate, respectively, over or underestimation (Szulczewski et al. 2010). When the level of trust $\alpha=0.05$ it was verified that there is no reason why the hypothesis of fit of errors of model with the normal distribution should be rejected. In addition, two measurements characterising the approximation error were assumed: coefficient of correlation $r$, and average relative error of deviations $\mathrm{Bw}$ which is the measure of the difference in the biogas productions achieved from the model and direct measurements. The model developed was verified with the Cross Validation (CV) test in the LOO version due to the relatively small number of data (Picard and Cook 1984).

Table 1 shows the results achieved which demonstrate a good prediction of the calculator. The coefficient of determination for approximation and validation indicates a satisfactory fit of the model to the empirical data. None of the values is smaller than 0.6. Also the other coefficients, such as the model efficiency, the relative root mean square error or the measurement of the relation between the measured and forecast values, indicate a good fit of the calculator. In the case of evaluation of the model without taking into account the beet pulp, the absolute error was smaller (for approximation $28.87 \%$ for validation $30.01 \%$.) The remaining coefficients, except for CRM, also improved. In the case of agricultural biogas plants, due to small amount of data, the average relative error was calculated for each of the studied cases. The smallest relative error for the studied biogas plants was $8.34 \%$, and the biggest was $45.14 \%$. The average relative error for all six biogas plants was $23.13 \%$. The following is an example of a graph with actual average production for a specific duration of the process and for production calculated from the model. The initial deviation of the curve from the model results from the lack of data regarding the operation start-up of biogas plants. At further stage, the curve calculated from the model converges with the real curve (Fig. 4).

\section{Discussion}

The presented model can be used to estimate methane production only on the basis of known percentage of carbon content in the substrate and the inoculum which was used. Obviously, this model cannot be applied to simulate the fermentation process. For instance, it does not include such an important parameter as the temperature in the digester which greatly affects methane productionspecific species of Archaea live in different temperatures (Sowers 2000). It is, however, important that it can be used to estimate methane production from a given mixture, with the assumption that the other factors are appropriate for microorganisms. Unfortunately, it is not a universal relation. The analyses performed demonstrated that in many cases, although the conditions and carbon content were favourable, methane production for some substrates greatly differed from that which was expected. Several substrates greatly differed from the other ones, for instance, methane 
Table 1 Statistical measures used for the evaluation of the model

\begin{tabular}{lllllrl}
\hline & $r^{2}$ & $r$ & $E F$ & $R R M S$ & $C R M$ & $B w(\%)$ \\
\hline Approximation & 0.7 & 0.84 & 0.67 & 0.27 & 0.03 & 29.8 \\
Approximation without beet pulp & 0.79 & 0.89 & 0.77 & 0.24 & -0.07 & 28.9 \\
Validation & 0.61 & 0.78 & 0.59 & 0.3 & 0.03 & 34.5 \\
Validation without beet pulp & 0.78 & 0.88 & 0.68 & 0.29 & -0.07 & 30.0 \\
\hline
\end{tabular}

Fig. 4 Comparison of actual to estimated production

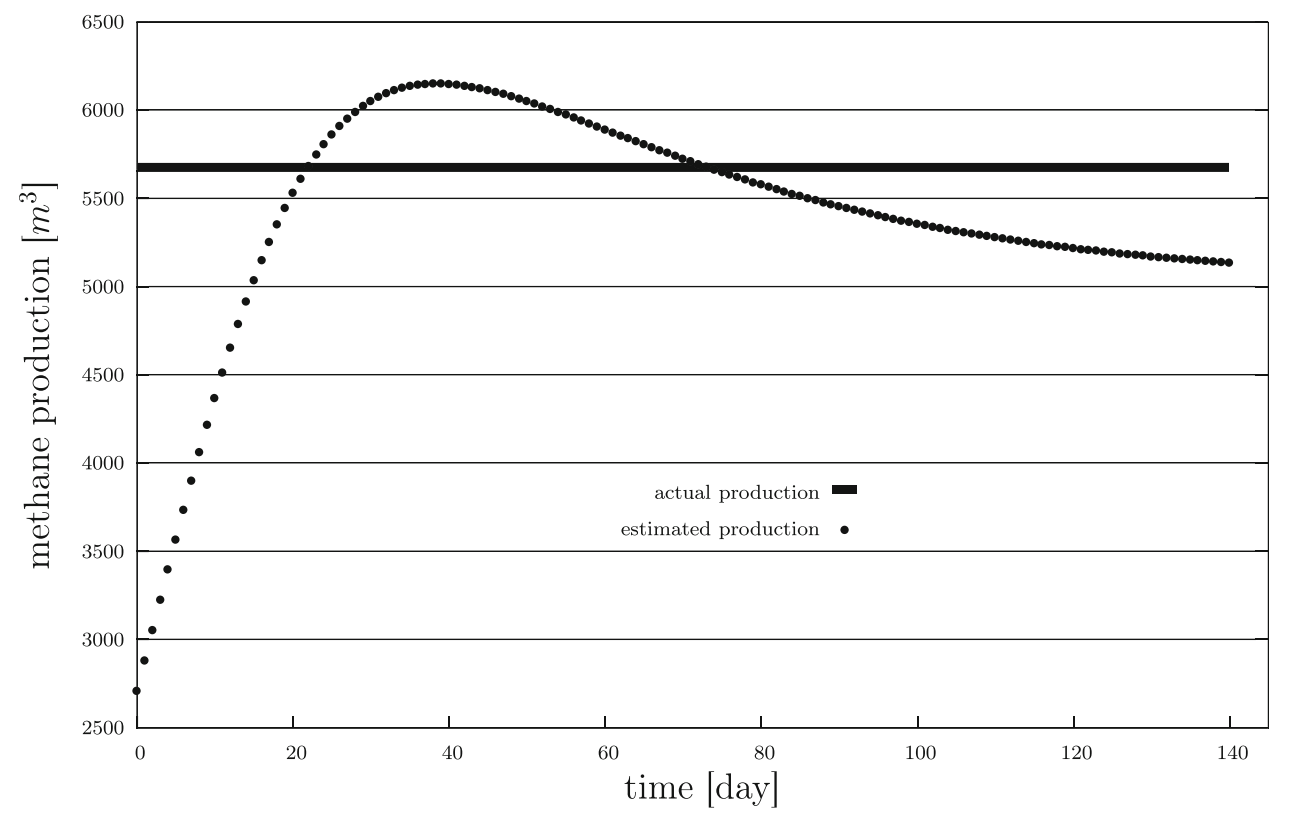

production from grass silage (percentage of carbon content in dry matter was over $7 \%$, and production was only 0.1 $\mathrm{ml} / \mathrm{g}$ ) - whereas the unit methane production from other substrates with lower carbon content, such as beet roots, was much bigger. Although carbon content was very low (about $2 \%$ carbon content in the mixture), methane production was very high. The following four groups were established on the basis of the analysis, based on the model developed, of the cases where methane production differed from the expected (Fig. 5).

1. The reason of poor methane production in the first group, which included animal faeces and silages, was the drop in $\mathrm{pH}$ which resulted from inadequate selection of the proportion of substrate and inoculum, e.g. in the case of liquid manure. Most probably it must be used with a substrate the $\mathrm{pH}$ of which is alkaline (Fugol and Szlachta 2013).

2. The second group included two substrates: phalaris and spartina. In both cases, it was impossible to estimate methane production because of the unknown lignin content (lignin does not hydrolyse in agricultural biogas plants Lalak et al. 2014).

3. Substrates with enzymatic additives were also used during the experiment. Actually, apart from millet with
ADP, carbon content of which was about $4 \%$, and methane production was close to $5 \mathrm{ml} / \mathrm{g}$, the other substrates in this group greatly differed from the model.

4. The last group included beet roots, methane production from which is unpredictable due to microorganisms in the soil, unless they are adequately prepared (roots are not free from sand and soil). This is so because soil microorganisms are introduced in the process (Fugol and Pilarski 2011).

In the case of analysis conducted in agricultural biogas plants, no production was found to be drastically different from what was expected. The level of error depended mainly on coefficients alpha and beta which were ultimately assumed at alpha $=0.03$ and beta $=1$ for all the analysed biogas plants.

\section{Conclusion}

From among the available mathematical models, most of which have been developed in the United States, it is very difficult to find one which would meet the following two criteria: effectiveness and ease of use. Only the biogas 
Fig. 5 Methane production for all substrates

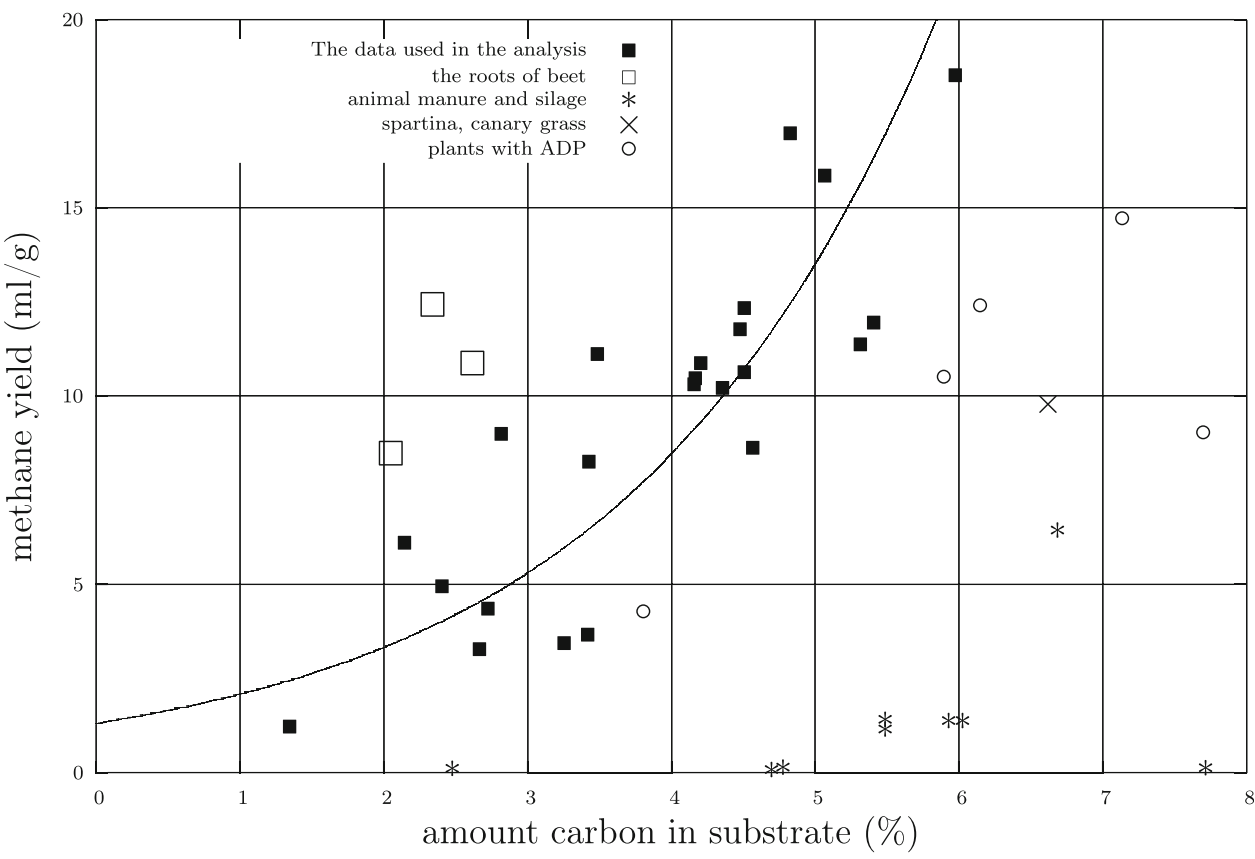

calculators use simple calculations, but unfortunately, their calculations of production yield are often burdened with unacceptable error. They estimate biogas production from the known content of dry matter, organic dry matter, and empirically established biogas production from substrate. Unfortunately, the last value established experimentally will be adequate only for a given substrate. In other cases, the results will greatly differ. The model presented in the paper estimates biogas production on the basis of the product of dry matter and the percentage of carbon content in dry matter in the mixture. With such an approach to the problem, it is possible to simplify the calculations (the same as biogas calculators) and to estimate production much more precisely in a wide range of cases.

However, it should be emphasised that the model presented here is not just a simplified version, but it also provides the foundations for the development of a more comprehensive model that would take into account other factors affecting methane production (e.g. temperature, $\mathrm{pH}$ ) and permit more complex analysis of methane formation in agricultural biogas plants.

Open Access This article is distributed under the terms of the Creative Commons Attribution 4.0 International License (http://creative commons.org/licenses/by/4.0/), which permits unrestricted use, distribution, and reproduction in any medium, provided you give appropriate credit to the original author(s) and the source, provide a link to the Creative Commons license, and indicate if changes were made.

\section{References}

Andara AR, Esteban MJL (1999) Kinetic study of the anaerobic digestion of the solid fraction of piggery slurries. Biomass Bioenerg 17:435-443
Axaopoulos P, Panagakis P, Tsavdaris A, Georgakakis D (2001) Simulation and experimental performance of a solar-heated anaerobic digester. Solar Energy 2:155-164

Battone DJ (2006) Mathematical modelling of anaerobic reactors treating domestic wastewater: rational criteria for model use. Rev Environ Sci Biotechnol 5:57-71

Behera SK, Meher SK, Park H (2015) Artificial neural network model for predicting methane percentage in biogas recovered from a landfill upon injection of liquid organic waste. Clean Techn Environ Policy 17:443-453

Chandra R, Takeuchi H, Hasegawa T, Kumar R (2012) Improving biodegradability and biogas production of wheat straw substrates using sodium hydroxide and hydrothermal pretreatments. Energy 43:273-282

El Monayeri DS, Atta NN, El Mokadem S, Aboulfotoh A (2013) Improvement of anaerobic digesters using pre-selected microorganisms. Int Water Technol J 3:45-59

Fugol M (2013) Ocena przydatności wybranych substratów pochodzenia rolniczego i przemysłowego do pozyskania biogazu na przykładzie wybranego powiatu rolniczego. $\mathrm{PhD}$ thesis, Wrocław University of Environmental and Life Sciences

Fugol M, Pilarski K (2011) Burak cukrowy jako substrat do biogazowni. Inz Rol 5(130):63-71

Fugol M, Szlachta J (2013) Use of the potato industry waste for anaerobic digestion. Przem Chem 92:824-828

Gerber M, Span R (2008) An analysis of available mathematical models for anaerobic digestion of organic substances for production of biogas. In: IGRC PARIS 2008 international gas union research conference, $1-30$

Hidalgo D, Martín-Marroquín MJ, Sastre E (2014) Single-phase and two-phase anaerobic co-digestion of residues from the treatment process of waste vegetable oil and pig manure. Bioenerg Res 7:670-680

Igliński B, Piechota G, Buczkowski R (2015) Development of biomass in polish energy sector: an overview. Clean Techn Environ Policy 17:317-329

Kameswari KSB, Kalyanaraman C, Umamaheswari B, Thanasekaran K (2014) Enhancement of biogas generation during co-digestion of tannery solid wastes through optimization of mix proportions of substrates. Clean Techn Environ Policy 16:1067-1080 
Lalak J, Kasprzycka A, Murat A, Paprota EM, Tys J (2014) Obróbka wstępna biomasy bogatej w ligninoceluloze w celu zwiekszenia wydajności fermentacji metanowej. Acta Agrophys 21(1):51-62

Latinwo GK, Agarry SE (2015) Modelling the kinetics of biogas generation from mesophilic anaerobic co-digestion of sewage sludge with municipal organic waste. Chem Process Eng Res 31:2224-7467

Ledakowicz S, Kacprzak A, Krzystek L (2010) Badania biochemicznego potencjału metanogennego wybranych roślin energetycznych. Inz Ap Chem 4:32-33

Masse DI, Droste RL (2000) Comprehensive model of anaerobic digestion of swine manure slurry in a sequencing batch reactor. Water Res 12:3087-3106

Menardo S, Bauer A, Theuretzbacher F, Piringer G, Nilsen JP, Balsari P, Pavliska O, Amon T (2013) Biogas production from steamexploded miscanthus and utilization of biogas energy and $\mathrm{Co}_{2}$ in greenhouses. Bioenerg Res 6:620-630

Minott JS (2002) Feasibility of fuel cells for energy conversion on the dairy farm. PhD thesis, Faculty of the Graduate School of Cornell University

Myczko A, Myczko R, Kołdziejczyk T, Golimowska R, Lenarczyk J, Janas Z, Kliber A, Karłowski J, Dolska M (2011) Budowa i eksplotacja biogazowni rolniczych. Poradnik dla inwestorów zainteresowanych budowla biogazowni rolniczych. ITP, 05-090 Raszyn, Polska, al. Hrabska 3

Pandey KP, Ndegwa MP, Soupir ML, Alldredge RJ, Marvin PJ (2011) Efficacies of inocula on the startup of anaerobic reactors treating dairy manure under stirred and unstirred conditions. Biomass Bioenerg 35:2705-2720

Picard RR, Cook RD (1984) Cross-validation of regression models. J Am Stat Assoc 79(387):575-583
Rath J, Heuwinkel H, Taube F, Herrmann A (2015) Predicting specific biogas yield of maize-validation of different model approaches. Bioenerg Res 8:832-842

Sattler M (2011) Anaerobic processes for waste treatment and energy generation. Integr Waste Manag 2:216-246

Schlegel GH (2003) Mikrobiologia Ogólna, drugie wydanie poprawione. Wydawnictwo Naukowe PWN SA, Warszawa

Sławiński K, Bujaczek R, Piskier T (2012) Ocena przydatności kalkulator'ow biogazowni przy planowaniu budowy biogazowni rolniczej. Inz Rol 4:369-375

Sowers RK (2000) Methanogenesis. In: Hurst CJ (ed) Encyclopedia of microbiology. Academic press, London, pp 204-226

Szulczewski W, Zyromski A, Biniak-Pieróg M, Machowczyk A (2010) Modeling of the effect of dry periods on yielding of spring barley. Agric Water Manag 97:587-595

Toprak H (1995) Temperature and organic loading dependency of methane and carbon dioxide emission rates of a full-scale anaerobic waste stabilization pond. Water Res 4:1111-1119

Wandrasz JW, Landrat M (2002) Model matematyczny wytwarzania biogazu w składowiskach odpadów. Ochr Srodowiska 2(85): $13-16$

William JJ (2000) Methane production/agricultural waste management. In: Ravdin JI, Greenberg HB, Guerrant RL (eds) Encyclopedia of microbiology. Academic press, New York, pp 199-203

Wu B, Bibeau EL, Gebremedhin GK (2006) Three-dimensional numerical simulation model of biogas production for anaerobic digesters. Agric Biol Eng 064060:2-29 